\title{
Erfaringer uden form
}

\author{
af Mette Tønnesen
}

\author{
Idræt og Agon \\ - Tekster om idrættens \\ ydre og indre miljø \\ Red. Olav Ballinger.
}

\section{Bogens bestanddele - og redaktørens hensigter}

Redaktøren af bogen Idræt og Agon, kalder bogen for en collage. Collagen udgøres af fjorten forskellige personers femten forskellige indlæg, hvoraf de fjorten er skriftlige og et enkelt er fotografisk. Billederne i det fotografiske indlæg er fordelt over hele bogen, ligesom seksten småhistorier med afsluttet forløb og moralske pointer er det. Disse parabellignende stykker er skrevet af redaktøren, Olav Ballisager, selv. Bogen har to hovedmotiver, som præsenteres på denne måde i redaktørens forord:

„Spørgsmålet om at finde den ultimative sandhed - mødet mellem livet og døden - har altid ligget mennesket på sinde. Grækerne kaldte denne kamp for livets højeste sandhed for AGON. I de mellemliggende århundreder har det til stadighed været diskuteret og afprøvet om denne søgen efter livets sandhed kunne opnås uden $i$ fysisk forstand at risikere selve livet som organisme. ... Et nøglepunkt til forståelsen af ,agon“ er at acceptere, at kampe ikke entydigt er en stræben efter materiel overlegenhed, men at der bagved ligger et kampmotiv af langt højere karat - kampen for hæder, kampen for sandhed. ... Agon-motivet er centralt stillet $i$ bogen. Begrebet har at gøre med bevidsthed og erkendelse i den kamp - eller dialog - der ligger ud over det rivaliserende. ... Idrættens ,ydre og Indre Miljø" - forholdet mellem naturen og menneskets personlige miljø - er et andet hovedtema, der direkte og indirekte behandles $i$ tekst og billeder." (s 7-8).

Hensigten med den 210 sider lange collage omkring disse to hovedmotiver, er bevidst at sætte sig mellem flere stole, for at provokere til eftertanke og debat. Men også ,,at højne den debat der er under udvikling og som er baseret på bl.a. sportens dobbeltrolle som formidler af ,,fredelig kappestrid 
mellem nationerne", samtidig med at kampene på banerne bliver hårdere og hårdere - og samtidig med, at idrætsfolk forbydes at bære fredssymboler på deres beklædning." (s 6).

Som det er fremgået af præsentationen indtil nu er emnerne og også de anlagte synsvinkler vidtspændende: fra det allermest abstrakte, at erfare hvad „liv" eller „død" er igennem udøvelse af idræt, til den konkrete diskussion af, hvorvidt en professionel idrætsudøver må bære fredssymboler på sit idrætstøj. Og så vidtspændende er bogens indlæg da faktisk også i emnevalg. Bogen rummer indlæg om: Den historiske udvikling i sportens fysiske rum (Præstation mellem vægge v. Henning Eichberg) beskrevet og sammenholdt med psykosociale træk ved forskellige samfundsgrupper. Kvindebevægelse og Idræt i Canada (Nancy Theberge). Agon Motivet, en gennemgang af, hvad kampudøvelse inden for et agonalt system må indeholde for komponenter, en undersøgelse af i hvilken udstrækning disse komponenter er underkastet forandringer og en vurdering af ændringernes indflydelse på det oprindelige konkurrencesystem (v. Robert Morford og S. Clark). Forslag til alternativ undervisningsplan for idræt (Hal A. Lawson). Kropslighed i punkkulturen (Barbarernes indtog v. Lars Alrø), og bare i de her nævnte indlæg findes vidt forskellige tilgange, emner, stillejer i fremstillingerne. Det er derfor ikke muligt i en kortfattet anmeldels som denne, at give noget, der nærmer sig et indholdsmæssigt referat af denne bog. Jeg har i stedet valgt at gå lidt nærmere ind på bogens form, hvad den jo netop også selv lægger op til - og at gå lidt nærmere ind på de sammenhængsskabende elementer den rummer.

\section{Hvad er stole - og hvad er mellemrum?}

I den brogede collage er Ballisagers egen stemme gennemgående. Dels via de fire indlæg, han har skrevet, hvoraf de to er indgangen til bogen, og det fjerde er bogens sidste indlæg. Dels via de parabelagtige småstykker, også skrevet af Ballisager, hvoraf de to i fortsættelse af Ballisagers sidste indlæg danner udløbet på bogen. Ballisagers indlæg er hver for sig meget løst struktureret, associerende skrevet. Hvert af dem behandler vidt forskellige emner som liv og død, skoleidræt kontra klubidræt i Danmark, børnenes klemte situation mellem fokusering på form og proces og prioritering af indhold og præstation, elite over for sundhedssalg, kultur- og uddannelsespolitik som socialpolitik, og ikke det omvendte kræves, vi opfordres til ikke at have tillid til administratorer og politikere, der nedprioriterer økonomisk støtte til kropsudfoldelse ... forførelsen af sportens egenidentitet og -form $i$ det teknologiserede kommunikationssamfund ... referat af interne diskussio- 
ner mellem sociologer, og mellem de refererede og Ballisager selv - og ja, det er ikke muligt at referere her. Det ville betyde et stort arbejde med at stoppe det ind i en struktur, en ordnet struktur, der lod sig fremstille lineært, for sådan en har de sprængfyldte indlæg ikke. Muligt er det imidlertid her at prøve at fremdrage nogle af de centrale holdninger, som går igen i Ballisagers indlæg, nemlig de holdninger, der fremkommer når han tager afsæt $\mathrm{i}$ et par af bogens centrale indlæg, for at diskutere sine hensigter, som han gerne vil gøre til vore fælles.

Idræts-/sportsudøvelse er godt, siger Olav Ballisager. Det har en egenidentitet og -form, nogle kvaliteter, som glimtvis skimtes i dele af det parantetiske liv idrætten/sporten har mulighed for at føre i vores samfund. Men kendskabet til og dermed muligheden for at bevare, dyrke, evt. endda udvide disse kvaliteter forudsætter en bevidstgørelse om deres karakter, og betingelser for deres eksistens. Vi skal gøre „idræt til kroppens humaniora“, foreslår Olav Ballisager forsigtigt. Vi skal sætte os det mål, at bevare det menneskeligt sammenhængende $i$ en branche præget af stadig større specialisering ( $p$ 90). Vi skal gøre det ved at begynde at ,,sortere i bunken af idrættens mål og midler" (p 86). Til dette konkrete punkt vender Olav Ballisager gentagne gange tilbage til eksemplet på konkrete modsigelser inden for undervisningsinstitutionelle sammenhænge. Her mener Ballisager at bl.a. den manglende erkendelse af præstationsmotivet som bærende i idræts-/sportsudøvelsens oplevelsesstruktur er skyld i, at også væsentlige tiltrækningskræfter ved idræts-/sportsudøvelse forsvinder, f.eks. tiltrækningen bundet til forestillingen om den mulige udnyttelse af individets ,,ultimative muligheder“ ( $p$ 14), netop indbygget $\mathrm{i}$ idræts-/sportsudøvelsen. Den manglende afklaring hos formidlerne medfører, mener Ballisager, at store grupper af befolkningen aldrig bliver gjort opmærksomme på - og derfor ikke ser, eller oplever, hvad han kalder sportens egenidentitet/-form.

Det er indkredsningen af de kvalitative aspekter ved sporten og idrætsudøvelsen, jeg ser som det væsentlige, det spændende, det nye blandt alle de mange aspekter der er at pege på såvel hos Ballisager selv, som i de øvrige indlæg i bogen. Indkredsningen af disse kvalitative aspekter ved kropserfaring bliver imidlertid ikke tildelt så fremtrædende en placering i bogen, som titlen ellers nok lægger op til. Når jeg nu skriver:

En utrolig ringe bevidsthed om sammenhænge mellem form og indhold, og en ringe bevidsthed om ydre og indre relationer, der medvirker til denne sammenhængs etablering. Et produkt, der minder om en sandkasse, præsenteret fuld af en bunke legetøj, til fri afbenyttelse. Uden tanke på, hvad af legetøjet, man kan få øje på udefra, hvem der ville kunne finde på at kigge nærmere efter i sandkassen, hvad der skulle til at få dem op i den, eller hvordan de skulle lege dér, så kunne disse konstateringer meget vel være 
citater fra Olav Ballisagers karakteristik af idrætten og dens miljø inden for undervisningsinstitutionerne i Danmark (s 22 Idræt og Agon). Men her har jeg skrevet dem som en karakteristik af bogen Idræt og Agon. Provokerende, måske, men lad mig prøve at forklare.

\section{Bogen som medium}

Det er paradoksalt, at netop denne bogs mest iøjnefaldende træk, mest dominerende træk, er dens uhyre opsplittede form. Det er paradoksalt fordi netop denne bogs indhold i høj grad plæderer for at skabe betingelser for, at individet og institutionerne får afklaret synspunkterne på idræt/sport, så det bliver muligt at overskue sammenhænge, prioritere, altså deltage som subjekt, og ikke bare passivt henfalde i strukturernes, reglernes vold. En opsplittet form kunne være den mest ideelle til formidlingen af et ikke umiddelbart sammenhængende stof. Men hvorfor er det ikke lykkedes her at fremhæve og tydeliggøre de, i hvert fald ifølge min læsning, væsentligste hensigter gemt bag bogen?

Forklaringen ligger efter min mening i en række faktorer omkring brugen af medium. Det er sjældent at møde en bog, hvor den manglende tilstedeværelse af bevidstheden om, at formidlingen foregår via mediet „,bog“ er så slående. Den irriterende ligegyldighed over for korrekturfejl og stavekonsekvens er medvirkende til læserens besværligheder med bogen, ligesom det totalt opbrudte satsbillede, der opstår, fordi almindelig tegnsætning, nyt afsnit etc. ikke har været tilstrækkeligt, medvirker. Der er tale om en overdrevet anvendelse af linjeoverspring, med det resultat, at så mange små tekststykker står fremhævet på siden, at ingen stykker reelt står fremhævede for læserens blik. Alle disse tekniske mangelfuldheder er med til at forstærke det uoverskuelige ved bogen. Yderligere medvirkende årsager til at bogen falder fra hinanden for læseren, skal findes i de elementer, der ellers kunne være sammenhængsskabende: Olav Ballisagers artikler og parabelagtige småstykker. De medvirker til splittelsen fordi de er holdt i en associerende snakkende form, hvor emner tages op uprioriterede og gentaget $i$ vidt forskellige sammenhænge. I allerførste indlæg virker det f.eks. som om Ballisager først havde sat sig for at præsentere forfatterne, men så glemmer sit ærinde og fortaber sig i sine egne associationer. Det er som om Olav Ballisager har valgt at springe op og falde ned på den helt nødvendige forudsætning og arbejdsbetingelse for mediet bog, at bogens realisering, dens ,,fødsel“ er afhængig af et enkeltindivids bevidst udøvede læsebevægelse. En bevægelse, der nødvendigvis er lineær, ikke øje-blik-ke-lig og samtidig som den visuelle oplevelse af et billede/ en collage. Vil man gøre en 
bog til collage, altså give indtryk af samtidig tilstedeværelse af en række vidt forskellige og kun tilsyneladende usammenhængende elementer kræver det en høj grad af bevidsthed over for det lineære medium. Det kunne være lykkedes med de midler bogen anvender, den tilbagevendende parabel og redaktørens strategisk placerede indlæg. Det havde imidlertid krævet en langt klarere prioritering og således selvdisciplinering - og ja, jeg havde nær sagt selvkritik fra Olav Ballisagers side. Hvad skal f.eks. sådan en relation som nr. 5? Under så stor en overskrift som „Frihedskamp“ at placere et angreb på dansk lovjungle og lade det munde ud $\mathrm{i}$ et suk over, at danskerens faren vild $i$ den optager al hans livsenergi - det synes jeg er langt ude, og glansen går noget tabt ved alle de store flotte lidenskaber når man medtager den slags intetheder.

\section{- og kroppens hukommelse}

Som den læsende af denne anmeldelse, der stadig hænger på, sikkert har gættet føler undertegnede anmelder sig imidlertid alligevel dybt berørt af IDRETT OG AGON. AErgrelsen over at det ikke er lykkedes at få form og indhold til at gå op i en højere enhed skyldes anmelderens dybeste sympati med det, hun tror projektet går ud på. Det skal ganske kort forsøges illustreret her $i$ det allersidste afsnit, hvor anmelderen vil inddrage en enkelt relation, for at tale Ballisagersk, nemlig en fortælling af forfatterinden Christa Wolf KASSANDRA. I først omgang vil jeg forsøge mig med et par citater fra fortællingen - som jeg i øvrigt ikke kan komme nærmere ind på her - for at angive, hvor sammenhængen med IDR/ET OG AGON for mig at se findes.

Ultrakort introducerende skal blot siges, at fortællingen udspilles som et erindringsforløb om en periode umiddelbart før, under, og efter afviklingen af en krig mellem grækere og trojanere. En krig, hvor en figur kaldet ,,den smukke Helene" spillede en væsentlig rolle. Citaterne gengivet her er Kassandras tanker, mod erindringsforløbets afslutning og Kassandras egen død:

„Jeg havde en følelse af, at jeg med min krop overdækkede det sted, hvor andre virkeligheder sivede ind $i$ vor verden af faste legemer, noget kun jeg kunne mærke. Verdener som de fem sanser, vi er blevet enige om at bruge, ikke kan fatte, hvorfor vi må fornægte dem" (o.c. s 114)

„For grækerne findes der kun enten sandhed eller løgn, rigtigt eller forkert, sejr eller nederlag, ven eller fjende, liv eller død. De tænker anderledes. Hvad der ikke er synligt, til at lugte, høre, røre ved, eksisterer ikke. Det er det andet, som de maser i stykker mellem deres skarpe distinktioner, Det Tredje, som efter deres mening overhovedet ikke findes, det smilende, levende, som er $i$ 
stand til gang på gang at frembringe sig selv ud af sig selv, det ikke-adskilte, ånd $i$ livet, liv $i$ ånden. Anchises sagde engang, at evnen til indføling kunne have været vigtigere for dem end opfindelsen af det fordømte jern. At de ikke kun anvendte de jernhårde begreber godt og ondt på sig selv. Men for eksempel også på os. " (o.c. s 115)

„De fem sanser vi er blevet enige om at bruge", siger Kassandra, og underforstår den sjette - helheden af alle sanserne i brug på en gang - vores krops erindring. Og genkaldelsen af en bemærkning om menneskets evne til indføling. Indfølingsevnens historie. Hvorfor er tusindvis af mennesker $i$ stand til at føle sig ind $\mathrm{i}$ målscorerens situation? Agon har talt, siger Ballisager, ved beskrivelsen af Khrustjovs og Harrimans overværelse af et fantastisk højdespring, der forenede dem i omfavnelse. Indkredsningen af de kvalitative aspekter ved HELE individets udvikling, den går også, og måske slet ikke mindst over beherskelsen af den sproglige udtryksform $\mathrm{i}$ ord. Christa Wolf gør det overlegent i denne fortælling, Olav Ballisager gør det knapt så elegant, men det fornemmes klart, at der ligger erfaringer bag udtrykket, som blot skal finde en form. 